the Criminal Procedure Code of Ukraine indicating the possibility of using bail in committing criminal offenses.

We agree with the proposal to supplement part 1 of Article 335 and part 9 of Article 335 of the Criminal Procedure Code of Ukraine, the provision on resolving in the operative part of the conviction the issue of returning the pledge to the mortgagor in order to ensure the property rights of the mortgagor, the timeliness of the return of the pledge was proposed, because in case of its adoption will be settled.

Improving the quality of the criminal procedural legislation of Ukraine on the procedure for applying bail should, in our opinion, be to provide the possibility of bail in accordance with Article 182 of the Criminal Procedure Code of Ukraine in non-monetary form, which corresponds to such a general principle of criminal proceedings as the rule of law.

Keywords: precautionary measures, bail, quality of criminal procedural legislation of Ukraine, criminal procedural law of Ukraine; criminal justice.

DOI: $10.33766 / 2524-0323.91 .117-126$

УДК 343.7

Р. О. Мовчан, кандидат юридичних наук, доцент, доцент кафедри конституційного, міжнародного та кримінального права Донецького національного університету імені Василя Стуса

(м. Вінниця, Україна) e-mail: romanmov1984@gmail.com iD ttps:/ / orcid.org/0000-0003-2074-8895

\title{
ПРОБЛЕМИ ЗАСТОСУВАННЯ СТ. 48 КК УКРАЇНИ ЩОДО ОСІБ, ЯКІ ВЧИНИЛИ САМОВІЛЬНЕ ЗАЙНЯТТЯ ЗЕМЕЛЬНОЇ ДІЛЯНКИ ТА САМОВІЛЬНЕ БУДІВНИЦТВО
}

У статті розглянуто найбільш дискусійні питання, які виникають при звільненні від кримінальної відповідальності у зв'язку зі зміною обстановки осіб, котрі вчинили кримінальні правопорушення, передбачені ст. 197-1 Кримінального кодексу України. Аргументовано, що неправомірними є рішення тих судів, які застосовують ст. 48 Кримінального кодексу України лише на тій підставі, що особа позитивно характеризується за місцем проживання, щиро розкаялась у вчиненому кримінальному правопорушенні тощо. Водночас визначено випадки, коли таке застосування є законним та обгрунтованим.

Ключові слова: самовільне зайняття, земельна ділянка, самовільне будівництво, звільнення від кримінальної відповідальності, зміна обстановки, суспільна небезпека, кримінальне правопорушення.

Постановка проблеми. Аналіз судової практики за ст. 197-1 Кримінального кодексу України (далі - КК) «Самовільне зайняття земельної ділянки та самовільне будівнищтво» засвідчує, що однією з їі характерних тенденщій є те, що близько 50 \% винних осіб звільняються від кримінальної відповідальності, з яких більша частина (32 \%) - на підставі ст. 48 КК, котра передбачає звільнення від кримінальної відпові-

(C) Мовчан Р. О., 2020 
дальності у зв' язку зі зміною обстановки. Водночас з' ясовано, що при реалізації відповідних положень кримінального законодавства судові та правоохоронні органи перманентно стикаються з цілою низкою гостро дискусійних питань, уніфіковане бачення стосовно вирішення яких відсутнє не лише в практичних працівників, а й у науковців. Зокрема, було встановлено, що чи не найбілыше складнощів викликає опанування змісту вживаних у розглядуваній кримінально-правовій нормі понять «втрата суспільної небезпечності діянням» та «втрата суспільної небезпечності особою, яка вчинила діяння», неправильне тлумачення яких нерідко призводить до неправомірного застосування ст. 48 КК щодо осіб, які вчинили самовільне зайняття земельної ділянки та самовільне будівнищтво.

Аналіз останніх досліджень і публікацій. Проблематика звільнення від кримінальної відповідальності, зокрема, й у зв' язку зі зміною обстановки, у доктрині України традищійно належить до активно досліджуваних. Помітний вклад у їі розроблення внесли такі вітчизняні вчені-криміналісти, як: Ю. В. Баулін, О. О. Дудоров, О. О. Житний, 3. А. Загиней-Заболотенко, О. С. Козак, В.М.Куц, О. В. Перепадя, А. М. Ященко та інших. Визнаючи неабияку теоретичну та практичну значущість робіт названих авторів, водночас необхідно констатувати, що в білышості з них висвітлюються лише загальні питання звільнення від кримінальної відповідальності. Проте поза увагою залишаються проблемні аспекти застосування відповідної норми щодо осіб, які вчинили кримінальні правопорушення, передбачені ст. 197-1 КК.

Формулювання цілей. Метою статті є вирішення зазначених питань, які виникають при застосуванні ст. 48 КК щодо осіб, котрі вчинили самовільне зайняття земельної ділянки та самовільне будівнищтво.

Виклад основного матеріалу. Як відомо, ст. 48 КК передбачає дві самостійні підстави звільнення від кримінальної відповідальності: 1) втрата внаслідок зміни обстановки суспільної небезпечності вчиненого діяння; 2) втрата внаслідок зміни обстановки суспільної небезпечності особи, яка вчинила відповідне діяння.

Стосовно втрати суспільної небезпечності вчиненого діяння, зміна обстановки означає передусім істотну зміну сощіально-економічних, політичних або духовних засад життєдіяльності суспільства, яка відбувається незалежно від волі винної особи і внаслідок чого втрачається суспільна небезпечність не лише конкретного кримінального правопорушення, а й подібних йому діянь (наприклад, скасування надзвичайного стану, перехід країни від воєнного часу до мирного або від однієї системи господарювання до принципово іншої). Зазначені масштабні зміни зазвичай передують рішенню законодавця декриміналізувати ті чи інші діяння. Зміна обстановки може стосуватись як усієї країни, так і окремих територій, населених пунктів, підприємств, установ, організацій. Зміни в мікросоціальному середовищі, так би мовити, «знецінюють» шкоду, заподіювану конкретним посяганням, і тим самим усувають суспільну небезпечність діяння загалом [1, с. 24].

Ю. В. Баулін розрізняє локальну, унаслідок якої втрачається суспільна небезпечність конкретного злочину르, i масштабну зміну обстановки, яка тягне за собою

\footnotetext{
1 Як відомо, 31 липня 2020 р. у системі кримінального законодавства України запроваджено двочленну класифікацію кримінальних правопорушень із поділом їх на злочини та кримінальні проступки. Однак у цій статті при посиланні на раніше опубліковані роботи та рішення
} 
втрату суспільної небезпечності певного виду злочинних діянь, «коли законодавець не встигає змінити ознаки відповідного складу злочину або зовсім виключити його iз KK» [2, с. 151]. Вдало розв'язує проблему співвідношення звільнення від кримінальної відповідальності у зв'язку зі зміною обстановки й декриміналізації П. Л. Фріс, який виокремлює два види втрати діянням суспільної небезпечності: 1) втрата суспільної небезпечності конкретним злочином як результат змін локального характеру, що не призводять до законодавчих змін; 2) втрата злочином суспільної небезпечності, пов' язана з глобальними змінами в країні, які, внаслідок динамічності соціальнополітичних процесів, поки що не призвели до змін у законодавстві [3, с. 343]. Саме друга ситуація нерідко передує рішенню законодавця про декриміналізацію певних діянь, оперативне кримінально-правове реагування на які до ухвалення такого рішення може набувати вигляду застосування ст. 48 KК.

Загалом про перший вид зміни обстановки (масштабна зміна) в контексті самовільного зайняття земельної ділянки говорити наразі не доводиться. А ось локальна зміна обстановки, як підстава звільнення від кримінальної відповідальності за вчинення розглядуваного кримінального правопорушення, неодноразово вказувалася в досліджених процесуальних документах. Водночас, мотивуючи свої рішення про втрату діянням суспільної небезпеки, суди переважно посилаються на три обставини:

1) отримання або намір отримати винною особу у встановленому законом порядку право на землю.

Подільський районний суд м. Київ визнав вчинене Особою-1 діяння таким, що перестало бути суспільно небезпечним, через те, що обвинувачений визнав свою вину, щииро покаявся та, головне, отримав дозвіл для встановлення тимчасової споруди, самовільне розміщення якої і стало підставою для інкримінування ст. 197-1 КК [4];

2) відшкодування збитків, завданих самовільним зайняттям земельної ділянки.

Одним із судів Особа-1 звільнении від кримінальної відповідальності за вчинення злочину, передбаченого ч. 2 cm. 197-1 КК, на тій підставі, що самовільно встановлений торгівельний кіоск було демонтовано, икода, спричинена порушенням законодавства, була відикодована В повному обсязі, що, на думку суду, свідчить про втрату вчиненим Особою-2 діянням суспільної небезпечності [5];

3) добровільне звільнення винною особою самовільно зайнятої земельної ділянки, що викликає чи не найбільше занепокоєння, коли відповідні рішення суди пояснюють самим лише цим фактом.

Дніпропетровський районний суд Дніпропетровської області, керуючись ст. 48 КК, звільнив від кримінальної відповідальності Особу-1 на тій підставі, що останній звільнив самовільно зайняту земельну ділянку та повністю визнав свою вину у вчиненні злочину [6].

Така практика застосування ст. 48 КК явно не стимулює законослухняну поведінку, оскільки в найгіршому разі тому, хто вчинив самовільне зайняття земельної ділянки, загрожує хіба що необхідність укласти відповідний договір і внести орендну плату за користування земельною ділянкою або звільнити земельну ділянку, не зазнаючи будь-якого негативного кримінально-правового наслідку за вчинене. I хоча в юридичній літературі наголошується, що перетворювати кримінальне право

судів інколи буде яким до набрання чинності відповідних змін позначалися будь-які кримінально протиправні діяння. 
на «нагороджувальну», «заохочувальну» галузь немає підстав [7, с. 172], у частині застосування ст. 48 КК до осіб, які вчинили самовільне зайняття земельної ділянки, воно набуло саме таких, непритаманних йому рис.

Натомість, як приклад (на жаль, чи не єдиний) правильного розуміння юридичної природи приписів ст. 48 КК, можна навести рішення Апеляційного суду Донецької області.

Слов'янським міськрайонним судом Донецької області Особа-1 була звільнена від кримінальної відповідальності на підставі ст. 48 КК за вчинення злочину, передбаченого ч. 2 ст. 197-1, через те, що: нею було ліквідовано об'єкти, самовільно розташовані на земельній ділянці; остання звільнена та приведена в первісний стан [8]. Це рішення було оскаржене прокурором, за результатом розгляду скарги якого Апеляційний суд Донецької області обгрунтовано вказав на те, щуо зазначені дії Особи-1 свідчать про те, щзо вона лише припинила злочинну діяльність та усунула наслідки кримінального правопорушення, щуо не може бути підставою для застосування ст. 48 КК, адже обставин, які б дійсно свідчили про зміну обстановки, не встановлено [9].

Проте ще білыш неприйнятна ситуація склалася в частині звільнення від кримінальної відповідальності у зв'язку зі зміною обстановки, коли таке звільнення мотивується втратою особою суспільної небезпеки.

Як зазначається в п. 7 ППВСУ від 23 грудня 2005 р. № 12 «Про практику застосування судами України законодавства про звільнення особи від кримінальної відповідальності», особу можна визнати такою, що перестала бути суспільно небезпечною, у разі коли вона сама або обстановка навколо неї зазнала таких змін, що унеможливлюють вчинення нею нового злочину. Це зміни умов життєдіяльності конкретного суб'єкта, які позитивно й дієво впливають на нього, з великою долею ймовірності свідчать про те, що він не вчинятиме в майбутньому кримінально караних діянь, принаймні, подібних до вже вчиненого, адже «неможливо вимагати від суду, щоб на підставі оцінки зміни обстановки він прогнозував взагалі неможливість вчинення даною особою будь-якого злочину, навіть необережного» [2, с. 156].

Фактами зміни зовнішньої обстановки, яка оточує винного, можуть визнаватися, зокрема: призов на строкову військову службу; зміна постійного місця проживання й розірвання зв' язків із кримінальним оточенням, під впливом якого було вчинено злочин; звільнення з роботи, через виконання якої було вчинено злочин; працевлаштування раніше не працюючого; тяжка хвороба або нещасний випадок, унаслідок чого особа стала інвалідом; ув'язнення себе в монастирі; залучення особи до конфіденційної співпращі з правоохоронними органами; звільнення в запас військовослужбовця строкової служби, який учинив самовільне залишення військової частини або місця служби; інвалідність дитини чи дружини такого військовослужбовця; смерть дружини військовослужбовця, який учинив самовільне залишення військової частини або місця служби, або позбавлення батьківських прав такої дружини, що потягло за собою залишення спільної дитини без піклування батьків; поліпшення сімейних стосунків, ускладнення яких у минулому сприяло вчиненню злочину; залишення неблагополучної, конфліктної сім’ї; вступ до шлюбу з жертвою злочину. У новому оточенні морально-юридична оцінка конкретної особи істотно змінюється; втрачається доцільність застосування щодо винного в злочині заходів кримінально-правової репресії [2, с. 154]. 
Жмеринським міськрайонним судом Вінницької області Особа-1, який вчинив злочин, передбачений ч. 2 cm. 197-1 КК, був визнаний таким, щу втратив свою суспільну небезпечність, зокрема і через звільнення иоого із посади керуючого ПП «УкрТерраПлюс», щзо позбавляе його можливості вчиняти нові злочини з використанням такої посади [10].

В одній із інших справ за ч. $1 \mathrm{~cm}$. 197-1 КК Особа-2 була звільнена від кримінальної відповідальності у зв'язку зі зміною обстановки, оскільки вона захворіла та особисто не могла взяти участь у судових засіданнях через погіршення стану здоров'я; пересування будь-яким транспортом для Особи-2 обмежено [11].

Водночас змушений констатувати, що в практиці застосування ст. 48 КК щодо випадків самовільного зайняття земельних ділянок та самовільного будівництва домінуючим є підхід, коли під втратою особою суспільної небезпеки суди розуміють зовсім інші обставини.

Наприклад, вивчивии письмові матеріали кримінального провадження, Великолепетиський районний суд Херсонської області зазначив, щуо Особа-1 вперше вчинив злочин невемикої тяжкості, за місием проживання характеризується позитивно, розкаявся, на час розгляду кримінального провадження його не можна вважати суспільно небезпечною особою, а тому суд въажає можливим збільнити Особу-1 від кримінальної відповідальності у зв'язку зі зміною обстановки та закрити кримінальне провадження [12].

Подібні за змістом рішення ухвалювали й інші суди, які втрату суб'єктом кримінального правопорушення суспільної небезпечності пояснювали тим, що він:

- «щиросердечно розкаявся та активно сприяв у розкритті злочину, негативно оцінює свою поведінку» [13];

- «займається суспільно-корисною працею, бере активну участь у громадському житті, позитивно характеризується за місцем проживання» [14];

- «повністю визнав свою провину і щиросердно розкаявся у вчиненому, 34 червня 2014 р. не працює у ТОВ» тощо [15].

Отже, звільняючи винних у самовільному зайнятті земельних ділянок та самовільному будівнищтві від кримінальної відповідальності на підставі ст. 48 КК, суди найчастіше враховують такі фактори, як позитивна характеристика за місцем проживання, відсутність судимості, зайняття суспільно корисною працею, відшкодування шкоди, приведення земельної ділянки в попередній стан, набуття прав на земельну ділянку, щире каяття, сприяння органам досудового розслідування. Як бачимо, більшість із цих обставин за своєю природою є суб'єктивними, і це тоді, коли в кримінально-правовій науці зміна обстановки належить до об'єктивних підстав звільнення від кримінальної відповідальності [16, с. 37]. Посилання в контексті застосування ст. 48 КК на такі різновиди позитивної посткримінальної поведінки особи, як відшкодування збитків, сприяння розкриттю злочинів, щире каяття тощо загалом є недоречним. Зазначене посилання ігнорує той факт, що зміна обстановки як об' єктивний вид звільнення від кримінальної відповідальності не залежить від волевиявлення й посткримінальної поведінки суб'єкта. Зроблений висновок, серед іншого, бере до уваги етимологію терміна «обстановка» (сукупність умов, за яких щось відбувається). У ст. 48 йдеться про зміну обстановки - про об'єктивні та суб'єктивні (тобто залежні від вольових зусиль особи), але в будь-якому разі зовнішні чинники втрати особою суспільної небезпечності. 
Вочевидь, саме через це М. І. Хавронюк розглядуваний вид звільнення від кримінальної відповідальності відносить не до заохочувальних, а до «квазізаходів» кримінально-правового впливу, які характеризуються тим, що не існує жодної «заслуги» особи в тому, що закон раптово став «прихильним» до неї, як немає й жодної заслуги держави - ні щодо виправлення особи, ні щодо запобігання вчиненню нових кримінальних правопорушень нею та іншими особами. «Квазізаходи застосовуються тому, що «просто так сталося», або через політичну, економічну чи іншу доцільність» [17, с. 302]. Аналогічно висловлюється і 3. А. Загиней-Заболотенко, зауважуючи, що в разі зміни обстановки винувата особа займає пасивну позищію стосовно впливу на певні зовнішні умови, які існують навколо [18, с. 118].

Оцінюючи ж наведені приклади із правозастосовної практики, пригадуються слова Ю. В. Бауліна про те, що не відповідає вимогам закону застосування ст. 48 КК без зміни обстановки лише з мотивів недоцільності притягнення до кримінальної відповідальності певної особи, яка вчинила злочин невеликої або середньої тяжкості [2, с. 156]. Слушними є й міркування С. С. Яценка, який зазначає, що звільнення від кримінальної відповідальності через зміну обстановки треба відрізняти від явкиз повинною, щирого розкаяння, сприяння в розкритті злочину та інших обставин, які лише пом' якшують відповідальність [19, с. 345].

Правильним у цьому аспекті може вважатися таке судове рішення.

До одного із судів надійшио клопотання прокурора про звільнення від кримінальної відповідальності у зв'язку зі зміною обстановки Особи-1, який обвинувачувався у вчиненні злочину, передбаченого ч. 2 cm. 197-1 КК. Клопотання було мотивовано тим, щуо Особа-1 повністю визнав свою вину, шзиро покаявся та звільнив самовільно зайняті земельні ділянки. Розглянувши відповідне клопотання, суд зазначив, що для застосування ст. 48 КК необхідно встановити, що після вчинення певного злочину обстановка змінилася так, що вчинене діяння вже не є суспільно небезпечним; посилання прокурора як на ознаки зміни обстановки на ті зазначені вище обставини не відповідають змісту зміни обстановки. 3 огляду на це суд обгрунтовано відмовив прокурору в задоволенні його клопотання [20].

На підтримку заслуговують і рішення деяких інших судів, які, демонструючи принципову позищію, замість звичного формального підходу, ретельно вивчають наявність підстав для задоволення відповідних клопотань.

Наприклад, розглянувии подібне клопотання щодо Особи-2, яке було мотивоване тим, що «самовільно зайнята земельна ділянка була звільнена від піску, а Особа-2 звільнився з посади директора, внаслідок чого перестав бути суспільно небезпечним», суд зауважив, що Особа- $є$ єтакожі ізасновником вказаного товариства, побто ӥ дотепер може керувати ТОВ. Крім того, Особа-2 самовільно зайняв земельну ділянку під розташування пішзаної суміші й тимчасової споруди. Водночас про звільнення вказаної ділянки від тимчасової споруди не йдеться. Посилаючись на ці обставини, суд відмовив у задоволенні клопотання [21].

Подібна аргументація покладена і $в$ основу рішення Кам'янсько-Дніпровського районного суду Запорізької області, яким було з'ясовано, що «ні коні, ні обладнання із самовільно зайнятої земельної ділянки вивезені не були, кінно-спортивні заходи продовжуються». Тому клопотання захисника Особи-3 про звільнення останнъого від кримінальної відповідальності через вттрату суспільної небезпеки задоволенню не підлягає [22].

Висновки. Отже, з огляду на вищевикладене, можна зробити висновок про незаконність рішень судів, які звільняють винних у самовільному зайнятті земельної ділянки та самовільному будівнищтві від кримінальної відповідальності у зв' язку зі зміною 
обстановки лише на тій підставі, що особа позитивно характеризується за місцем проживання та щиро розкаялась у вчиненому кримінальному правопорушенні. Застосування ст. 48 КК є можливим лише за реальної втрати діянням або винною особою суспільної небезпеки, що в практищі застосування цієї норми щодо осіб, винних у вчиненні кримінальних правопорушень, передбачених ст. 197-1 КК, насправді має поодинокий характер (лише 8 \% зі всього масиву проаналізованих проваджень).

Водночас питання щодо можливості застосування до осіб, які вчинили кримінальні правопорушення, передбачені ст. 197-1 КК, інших видів звільнення від кримінальної відповідальності, має стати предметом подальших наукових досліджень у сфері окресленої проблематики.

\section{Використані джерела:}

1. Мальцев В. Освобождение от наказания в связи с изменением обстановки. Уголовное право. 2008. № 6. С. 23-26.

2. Баулін Ю. В. Звільнення від кримінальної відповідальності. Київ: Атіка, 2004. 296 с.

3. Фріс П. Л. Кримінальне право України. Загальна частина: підручник. 2-ге вид., допов. і перероб. Київ: Атіка, 2009. 512 с.

4. Постанова Подільського районного суду м. Києва від 30 липня 2012 р. у справі 2607/6666/12. URL:http:/ / www.reyestr.court.gov.ua/Review/25523686.

5. Ухвала Кіровського районного суду м. Дніпропетровська від 16 червня 2015 р. у справі № 203/3535/15-к. URL:http:/ / www.reyestr.court.gov.ua/Review/45196627.

6. Ухвала Дніпропетровського районного суду Дніпропетровської області від 22 травня 2015 р. у справі № 175/1879/15-к. URL:http:/ / www.reyestr.court.gov.ua/Review/46081967.

7. Орловська Н. А. Стимулювання, прощення, заохочення: кримінально-правова інтерпретація. Право і суспільство. 2015. № 3. Ч. 3. С. 168-173.

8. Ухвала Слов'янського міськрайонного суду Донецької області від 22 вересня 2017 p. у справі № 243/6788/17. URL:http:/ / www.reyestr.court.gov.ua/Review/69052536.

9. Ухвала Апеляційного суду Донецької області від 23 листопада 2017 р. у справі № 243/6788/17. URL: http://www.reyestr.court.gov.ua/Review/70511112.

10. Ухвала Жмеринського міськрайонного суду Вінницької області від 9 вересня 2015 р. у справі 1- кп/130/107/2015. URL:http:/ / www.reyestr.court.gov.ua/Review/4992149.

11. Ухвала Апостолівського районного суду Дніпропетровської області від 20 червня 2014 р. у справі № 171/1686/13-к. URL:http:/ / www.reyestr.court.gov.ua/Review/39422148.

12. Ухвала Великолепетиського районного суду Херсонської області від 23 жовтня 2013 р. у справі № 649/907/13-к. URL:http:/ / www.reyestr.court.gov.ua/Review/35290425.

13. Ухвала Новосанжарського районного суду Полтавської області від 9 грудня 2016 p. у справі № 542/1704/16-к. URL: http:/ / www.reyestr.court.gov.ua/Review/63382083.

14. Постанова Хустського районного суду Закарпатської області від 16 серпня 2013 р. у справі № 713/98/12. URL: http:/ / www.reyestr.court.gov.ua/Review/33023352.

15. Ухвала Дніпропетровського районного суду Дніпропетровської області від 15 вересня 2014 р. у справі № 175/3339/14-к. URL:http:/ / www.reyestr.court.gov.ua/Review/40851785.

16. Головко Л. Классификация основ освобождения от уголовной ответственности. Законность. 1998. № 1. С. 36-40.

17. Кримінальне право: навч. посіб. / О. О. Дудоров, М. І. Хавронюк; за заг. ред. М. I. Хавронюка. Київ: Ваіте, 2014. 944 с.

18. Загиней 3. Аналіз судової практики стосовно звільнення від кримінальної відповідальності за декларування недостовірної інформації (стаття 366-1 Кримінального кодексу України). Історико-правовий часопис. 2018. № 2. С. 115-120. 
19. Кримінальне право України. Загальна частина : підручник для студентів юридичних вузів і факультетів / Г. В. Андрусів, П. П. Андрушко, В. В. Бенківський та ін.; за ред. П. С. Матишевського. Киӥв: Юрінком Інтер, 1997. 512 с.

20. Ухвала Петропавлівського районного суду Дніпропетровської області від 25 квітня 2019 р. у справі № 188/107/19. URL:http:/ / www.reyestr.court.gov.ua/Review/81442932.

21. Ухвала Голосївського районного суду м. Києва від 20 квітня 2015 р. у справі № 752/3767/15-к. URL:http://www.reyestr.court.gov.ua/Review/43748789.

22. Постанова Кам' янсько-Дніпровського районного суду Запорізької області від 23 вересня 2011 р. у справі № 1-114/11. URL:http:/ / www.reyestr.court.gov.ua/Review/55510650.

\section{References:}

1. Maltsev, V. (2008). Osvobozhdenye ot nakazanyia v sviazy s yzmenenyem obstanovky. Ugolornoe pravo- Criminal law, 6, 23-26. [in Russian].

2. Baulin, Yu. V. (2004). Zvilnennia vid kryminalnoi vidpovidalnosti Kyiv: Atika. [in Ukrainian].

3. Fris, P. L. (2009). Kryminalne pravo Ukrainy. Zahalna chastyna: pidruchnyk. Kyiv: Atika [in Ukrainian].

4. Postanova Podilskoho raionnoho sudu m. Kyieva vid 30 lypnia 2012 r. u spravi 2607/6666/12. (2012) N. p. URL:http://www.reyestr.court.gov.ua/Review/25523686. [in Ukrainian].

5. Ukhvala Kirovskoho raionnoho sudu m. Dnipropetrovska vid 16 chervnia 2015 r. u spravi № 203/3535/15-k. (2015) N. p. URL:http://www.reyestr.court.gov.ua/Review/45196627. [in Ukrainian].

6. Ukhvala Dnipropetrovskoho raionnoho sudu Dnipropetrovskoi oblasti vid 22 travnia 2015 r. u spravi № 175/1879/15-k. (2015) N. p. URL:http:// www.reyestr. court.gov.ua/ Review/46081967. [in Ukrainian].

7. Orlovska, N. A. (2015). Stymuliuvannia, proshchennia, zaokhochennia: kryminalnopravova interpretatsiia. Pravo i suspilstvo - Law and Society, 3, 168-173. [in Ukrainian].

8. Ukhvala Slov' ianskoho miskraionnoho sudu Donetskoi oblasti vid 22 veresnia $2017 \mathrm{r}$. u spravi № 243/6788/17. (2017) N. p. URL:http:/ / www.reyestr.court.gov.ua/Review/69052536. [in Ukrainian].

9. Ukhvala Apeliatsiinoho sudu Donetskoi oblasti vid 23 lystopada 2017 r. u spravi № 243/6788/17. (2017) N. p. URL:http://www.reyestr.court.gov.ua/Review/70511112/. [in Ukrainian].

10. Ukhvala Zhmerynskoho miskraionnoho sudu Vinnytskoi oblasti vid 9 veresnia $2015 \mathrm{r}$. u spravi1-kp/130/107/2015. (2015)N. p. URL:http://www.reyestr.court.gov.ua/Review/49921496. [in Ukrainian].

11. Ukhvala Apostolivskoho raionnoho sudu Dnipropetrovskoi oblasti vid 20 chervnia 2014 r. u spravi № 171/1686/13-k. (2014) N. p URL:http://www. reyestr.court.gov. ua/Review/ 39422148. [in Ukrainian].

12. Ukhvala Velykolepetyskoho raionnoho sudu Khersonskoi oblasti vid 23 zhovtnia $2013 \mathrm{r}$. u spravi № 649/907/13-k. (2013) N. p. URL: http://www.reyestr.court.gov.ua/Review/35290425. [in Ukrainian].

13. Ukhvala Novosanzharskoho raionnoho sudu Poltavskoi oblasti vid 9 hrudnia 2016 r. u spravi № 542/1704/16-k. (2016) N. p. URL: http://www.reyestr.court.gov.ua/Review/63382083. [in Ukrainian].

14. Postanova Khustskoho raionnoho sudu Zakarpatskoi oblasti vid 16 serpnia 2013 r. u spravi № 713/98/12. (2013) N. p. URL:http://www.reyestr.court.gov.ua/Review/33023352. [in Ukrainian]. 
15. Ukhvala Dnipropetrovskoho raionnoho sudu Dnipropetrovskoi oblasti vid 15 veresnia 2014 r. u spravi № 175/3339/14-k. (2014) N. p. URL:http://www.reyestr.court.gov.ua/Review/ 40851785. [in Ukrainian].

16. Golovko, L. (1998). Klassyfykatsyia osnov osvobozhdenyia ot uholovnoi otvetstvennosty. Zakonnost - Legality, 1, 36-40. [in Russian].

17. Dudorov, O. O., Khavroniuk, M. I. (2014). Kryminalne pravo: navch. posib. Kyiv: Vaite. [in Ukrainian].

18. Zahynei, Z. (2018). Analiz sudovoi praktyky stosovno zvilnennia vid kryminalnoi vidpovidalnosti za deklaruvannia nedostovirnoi informatsii (stattia 366-1 Kryminalnoho kodeksu Ukrainy). Istoryko-pravooyi chasopys - Historical and legal journal, 2, 115-120. [in Ukrainian].

19. Andrusiv, H. V., Andrushko, P. P., Benkivskyi, V. V. (1997). Kryminalne pravo Ukrainy. Zahalna chastyna: pidruchnyk dlia studentiv yurydychnykh vuziv i fakultetiv. Kyiv: Yurinkom Inter. [in Ukrainian].

20. Ukhvala Petropavlivskoho raionnoho sudu Dnipropetrovskoi oblasti vid 25 kvitnia 2019 r. u spravi № 188/107/19. (2019) N. p. URL: http:/ / www.reyestr.court.gov.ua/Review/81442932. [in Ukrainian].

21. Ukhvala Holosiivskoho raionnoho sudu m. Kyieva vid 20 kvitnia 2015 r. u spravi № 752/3767/15-k. (2015) N.p. URL:http://www.reyestr.court.gov.ua/Review/43748789. [inUkrainian]

22. Postanova Kam'iansko-Dniprovskoho raionnoho sudu Zaporizkoi oblasti vid 23 veresnia 2011 r. u spravi № 1-114/11. (2011) N. p. URL: http:/ / www.reyestr.court.gov.ua/Review/55510650. [in Ukrainia].

Стаття надійшла до редколегї 26.07.2020

Мовчан Р. А.

кандидат юридических наук, доцент, доцент кафедры конституционного, международного и уголовного права Донецкого национального университета имени Василия Стуса

(г. Винница, Украина)

\section{ПРОБЛЕМЫ ПРИМЕНЕНИЯ СТ. 48 УК УКРАИНЫ В ОТНОШЕНИИ ЛИЦ, СОВЕРШИВШИХ САМОВОЛЬНОЕ ЗАНЯТИЕ ЗЕМЕЛЬНОГО УЧАСТКА И САМОВОЛЬНОЕ СТРОИТЕЛЬСТВО}

В статье рассмотрены наиболее дискуссионные проблемы, которые возникают при освобождении от уголовной ответственности в связи с изменением обстановки лищ, совершивших уголовные правонарушения, предусмотренные ст. 197-1 Уголовного кодекса Украины.

Обосновано, что неправомерными являются решения тех судов, которые применяют ст. 48 Уголовного кодекса Украины лишь на том основании, что лицо положительно характеризуется по месту жительства и искренне раскаялось в содеянном уголовном правонарушении. В то же время определены случаи, когда такое применение является законным и оправданным.

Ключевые слова: самовольное занятие, земельный участок, самовольное строительство, освобождение от уголовной ответственности, изменение обстановки, общественная опасность, уголовное правонарушение. 


\section{Movchan R., \\ Candidate of Law, Associate Professor, Associate Professor of the Department of Constitutional, International and Criminal Law Vasyl' Stus Donetsk National University (Vinnitsa, Ukraine)}

\section{PROBLEMS OF APPLICATION OF ART. 48 OF THE CRIMINAL CODE OF UKRAINE REGARDING PERSONS WHO COMMITTED UNAUTHORIZED OCCUPATION OF LAND AND UNAUTHORIZED CONSTRUCTION}

The article discusses the most controversial problems that arise when exempt from criminal liability in connection with a change in the situation of persons who have committed crimes under Art. 197-1 of the Criminal Code of Ukraine.

In particular, it is argued that the existing practice of applying Art. 48 of the Criminal Code of Ukraine clearly does not stimulate law-abiding behavior, since in the worst case, the one who committed the unauthorized occupation of the land plot is only threatened by the need to conclude an appropriate contract and pay rent for the use of the land plot or vacate the land plot without experiencing any punishment for deed.

It is noted that exempting those guilty of unauthorized occupation of land plots and unauthorized construction from criminal liability on the basis of Art. 48 of the Criminal Code of Ukraine, the courts most often take into account such factors as a positive characteristic at the place of residence, no criminal record, engaging in socially useful work, compensation for harm, bringing a land plot to its previous state, acquiring rights to a land plot, sincere repentance, assistance to pre-trial investigation bodies. Reference in the context of the application of Art. 48 of the Criminal Code of Ukraine for these types of positive post-criminal behavior of a person is generally recognized as inappropriate, because it ignores the fact that a change of situation as an objective type of exemption from criminal liability does not depend on the expression of the will and post-criminal behavior of the perpetrator. In this regard, these decisions are recognized as illegal. But the decisions of other courts are supported, which, demonstrating a principled position, instead of the usual formal approach, carefully study the existence of grounds for satisfying the relevant applications for exemption from criminal liability in connection with a change in the situation on the basis of Art. 48 of the Criminal Code of Ukraine.

Keywords: unauthorized occupation, land, unauthorized construction, exemption from criminal liability, change of situation, public danger, criminal offense. 